\title{
Employment Instability and High Unemployment Rates
}

THE LABOR MARKET is in continuous internal motion, with workers moving rapidly between jobs, unemployment, and nonparticipation even during periods of stable economic activity. The flow of workers in and out of unemployment every month is always far greater than the increase in the number of the unemployed. For example, during the recent precipitous business contraction, when the unadjusted unemployment rate rose from 4.2 percent (October 1973) to 9.2 percent (June 1975), unemployment rose by an average of 231,000 workers each month. But during the same period, 2.7 million workers became unemployed on average every month, more than eleven times as many as the net increase. Since these heavy flows of workers are absorbed with only small month-to-month shocks to the unemployment rate, what kind of flows are generating the wide differentials in unemployment rates between disadvantaged workers and mature white males? Why are unemployment rates for blacks twice those for whites; those for mature females half again as large as those for males; and those for teenagers five times those for mature workers? And what happens to labor flows when unemployment rates double during recession?

Aside from the intrinsic interest of these questions, they are crucial to the current dilemma of inflation and unemployment. In recent years attempts to reduce unemployment through expansionary monetary and fiscal

Note: I wish to thank Ralph E. Smith and Jean E. Vanski for access to and help with the gross-flow data. I am grateful for research assistance by Leonard Herk, John O'Hare, and Lance Davidson; and for computer programming by Marjorie P. Odle. 
policies have run up against inflationary forces long before the unemployment of women, blacks, and teenagers could be reduced to frictional levels. These pockets of unemployment have kept the aggregate unemployment rate high and the noninflationary unemployment rate climbing as these groups have grown in the labor force. ${ }^{1}$ A flow analysis of the experience of these workers helps elucidate the special nature of their unemployment, and to explain why increased demand creates inflationary pressures before unemployment has been reduced to low levels.

The separation of unemployment into spells and duration has enhanced the understanding of labor markets available from static employment or unemployment data. ${ }^{2}$ But many of the studies of labor flows in the U.S. economy are limited to a world of two labor-market states: "unemployed" and "not unemployed." The fact that the latter state consists of two opposite conditions-being employed and being out of the labor force-is not unknown to the authors of these studies, but deficiencies in the data they used have prevented adequate analysis. In this paper I systematically evaluate flows between all possible labor-market states and conclude that employment outflows are the main cause of high unemployment rates among nonwhites, women, and teenagers. I then seek to determine the cause of this instability-in particular, the degree to which it can be associated with the characteristics of people and with the characteristics of their jobs.

\section{Transition Rates and Unemployment}

Studies based solely upon the duration of unemployment necessarily fail to distinguish job finding from labor-force exit. In consequence, the frequently cited result that disadvantaged demographic groups-blacks,

1. George L. Perry, "Changing Labor Markets and Inflation," BPEA, 3:1970, pp. 411-41.

2. Recent papers include Daniel B. Suits and Richard B. Morgenstern, "Duration as a Dimension of Unemployment," University of Michigan Research Seminar in Quantitative Economics (December 1967; processed); Hyman B. Kaitz, "Analyzing the Length of Spells of Unemployment," Monthly Labor Review, vol. 93 (November 1970), pp. 11-20; George L. Perry, "Unemployment Flows in the U.S. Labor Market," BPEA, 2:1972, pp. 245-78; Robert E. Hall, "Turnover in the Labor Force," $B P E A$, 3:1972, p. 735; Ralph E. Smith and Charles C. Holt, "A Job Search-Turnover Analysis of the Black-White Unemployment Ratio," in Gerald G. Somers (ed.), Proceedings of the Twenty-Third Annual Winter Meeting, 1970, Industrial Relations Research Association Series (IRRA, 1971), pp. 76-86. 
women, and teenagers-suffer higher unemployment rates primarily because of more frequent spells, rather than longer spells, may be misleading. It does not necessarily provide evidence that these groups find jobs as easily as mature white males do, but may reflect their tendency to give up job search and drop out of the labor force. ${ }^{3}$

To look at this question properly requires data on the flows of workers not only into and out of unemployment, but into and out of the labor force as well. In all, nine flows are involved in describing the labor market in this Markovian way:

\begin{tabular}{cccc}
$\begin{array}{c}\text { Labor-force } \\
\text { status in } \\
\text { previous } \\
\text { month }\end{array}$ & \multicolumn{3}{c}{$\begin{array}{c}\text { Labor-force status in } \\
\text { current month }\end{array}$} \\
\cline { 2 - 4 }$E_{t-1}$ & $E_{t}$ & $U_{t}$ & $N_{t}$ \\
$U_{t-1}$ & $E E$ & $E U$ & $E N$ \\
$N_{t-1}$ & $N E$ & $U U$ & $U N$ \\
& $N E$ & $N U$ & $N N$
\end{tabular}

Here, $E=$ employed, $U=$ unemployed, and $N=$ not in the labor force, and the symbols in the cells stand for the number of workers moving from the indicated state in the previous period to a given state in the current one. The probability of making such a transition, calculated by dividing the number of people in the flow by the number of people in the origin state, is designated by lower-case letters. For example, the probability that an employed worker will become unemployed, $E U / E$, is written $e u$. The flow probabilities are sometimes referred to as flow rates or transition rates.

Studies of the duration of unemployment relate to the flow $u u$, the probability of remaining unemployed. (The expected duration of unemployment is the reciprocal of $1-u u$.) And studies of the number of spells of unemployment relate to the flow probabilities $e u$ and $n u$ (usually without differentiating between them). Thus, not only is there more information to be mined from labor-market flows, but also the possibility exists that errors have crept into results from this concentration on the flows into and out of unemployment.

Fortunately, describing the system does not require information on all of the nine flows. Only two of the probabilities in each row are necessary,

3. Perry discusses this issue in "Unemployment Flows," pp. 275-78. 
because the fraction of people remaining in any one state is equal to unity minus the fraction that leaves to enter the other two states. These six independent transition probabilities can be transformed in many different ways, each of which suggests a slightly different interpretation of the transitions. In the present configuration the two flows from out of the labor force, $N U$ and $N E$, are separate and distinct, as though $N U$ s enter the labor force in order to become unemployed, while $N E$ s enter to get jobs. But by definition anyone entering the labor force does so to find a job, so it is more meaningful to sum these flows to obtain the probability of entering the labor force, $n e+n u$. The distinction between flows into jobs and flows into the unemployment pool is retained in the probability of successful labor-force entry:

$$
p n e=n e /(n e+n u) .
$$

Thus, the two probabilities $n u$ and $n e$ are mapped into the new probabilities, pne and $n e+n u$, which contain the same information but emphasize a more coherent interpretation.

These flow probabilities determine the relative number of people in each labor-market state and, since the unemployment rate is the number of unemployed workers expressed as a fraction of the labor force, they determine the unemployment rate. If the flows are constant over time this relationship can be expressed in a simple algebraic formula. In the so-called "steady state," employment remains constant because the flows into employment just compensate for the flows out of it:

$$
(u e) U+(n e) N=(e u+e n) E .
$$

Similarly the flows into unemployment equal the flows out of unemployment:

$$
(e u) E+(n u) N=(u e+u n) U .
$$

Eliminating $N$ from these two equations we find that

$$
\alpha E=\beta U,
$$

where

$$
\alpha=e u+(1-p n e)(e n)
$$

and

$$
\beta=u e+(p n e)(u n) \text {. }
$$

Equation 4 says that the three-state world can be thought of as a two- 
state world where the total flows from employment into unemployment $(\alpha E)$ are equal to the total flows from unemployment into employment $(\beta U)$. But equation 5 shows that the total probability of the flow from employment into unemployment $(\alpha)$ includes not only the probability that some workers will take this direct route $(e u)$, but the probability that some will become unemployed by first dropping out of the labor force and then reentering unsuccessfully $[(1-p n e)(e n)] .{ }^{4}$ The total flow rate from unemployment into employment $(\beta)$ is similarly composed of the probability of direct transitions $(u e)$ and the probability of indirect transitions [(pne)(un)].

The unemployment rate, defined as $U /(U+E)$, is then

$$
u=\frac{\alpha}{\alpha+\beta} \text {. }
$$

Equation 7 corresponds to the formula that represents the unemployment rate in the two-state case, ${ }^{5}$ except for the adjustments to $\alpha$ and $\beta$.

\section{Measuring Labor-Market Flows}

Any longitudinal survey holds the possibility of estimating flow rates by counting the fractions of workers in one state who were found in other states in the previous period. The Current Population Survey is partly longitudinal because it samples about 55,000 households subdivided into eight rotation groups, six of which are in the sample in two consecutive months. The data on "gross flows" are tabulations of the numbers of workers changing labor state from month to month within these six rotation groups. The probabilities of change mentioned in the previous section can then be estimated as the proportion of the individuals in the various

4. The probability of moving from $E$ to $N$ and from $N$ to $U$ in two steps is (en) (nu). In addition, some workers who made the transition from $E$ to $N$ remain in $N$ for $i$ periods and still become unemployed through unsuccessful labor-force entry. Their probability of making the journey from $E$ to $U$ is $(e n)(n n)^{i}(n u)$. Summing the probabilities of all transitions from $E$ to $U$,

$$
\alpha=e u+(e n)(n u) \sum_{i=0}^{\infty}(n n)^{i} .
$$

The infinite sum converges to $1 /(1-n n)$, so this expression for $\alpha$ can be converted to equation 5 by substitution of $1-p n e$ for $n u /(1-n n)$.

5. Hall, "Turnover in the Labor Force," p. 717. 
origin states in the first month who are found in the various destination states in the second month.

The accuracy of these gross-flow data has been challenged because they do not agree with counts of employment, unemployment, and people out of the labor force from the regular monthly CPS. ${ }^{6}$ For example, the change in unemployment between two months can be calculated in two ways: first, by subtracting the gross flows out of unemployment from the gross flows into unemployment; and, second, by subtracting the number of unemployed this month from the unemployed last month. The two methods fail to yield the same changes in the number of people in any of the three labor states. Most of the systematic difference appears to be due to "rotation group" bias: respondents are conditioned by the process of reinterview so that the gross-flow data, which exclude people interviewed for the first time or last time, will differ from data arising from the full CPS sample.

Fortunately, Holt and his associates have developed a regression technique that adjusts the gross flows to make them consistent with the full CPS sample. Their method is described elsewhere ${ }^{7}$ and the resulting data have been fitted to an econometric model for forecasting. ${ }^{8} \mathrm{My}$ goal is to see whether consistent patterns appear in demographic and cyclical differences in the flow probabilities.

\section{AVERAGE FLOWS}

The flow rates, reported by age, race, and sex, and averaged over the years 1967-73, appear in table 1. The transformed flow rates appear in the first column of table 2. Also in that table are the steady-state unemployment rates calculated from equation 7 using the flow rates, and the actual unemployment rates averaged from the CPS for each demographic group. The close correspondence of the unemployment rate calculated from gross flows to the official CPS unemployment rate shows that the data have been properly adjusted and that the steady-state formula is a good approximation for the unemployment rate.

6. Harvey J. Hilaski, "The Status of Research on Gross Changes in the Labor Force," Employment and Earnings, vol. 15 (October 1968), pp. 6-13.

7. Charles C. Holt and others, "Labor Markets, Inflation, and Manpower Policies," Final Report (Urban Institute, May 1975; processed), app. C.

8. Ralph E. Smith, "A Simulation Model of the Demographic Composition of Employment, Unemployment, and Labor Force Participation," Status Report, Working Paper 350-65 (Urban Institute, July 1974; processed). 
Table 1. Gross Labor-Flow Rates between States of the Labor Market, by Race, Sex, and Age, Monthly Average, 1967-73

Probability of individual in origin state in one month being in destination state in the second montha

\begin{tabular}{lcccccc}
\hline Race, sex, and age & $\begin{array}{c}\text { eu } \\
(I)\end{array}$ & $\begin{array}{c}\text { en } \\
(2)\end{array}$ & $\begin{array}{c}u e \\
(3)\end{array}$ & $\begin{array}{c}u n \\
(4)\end{array}$ & $\begin{array}{c}n e \\
(5)\end{array}$ & $\begin{array}{c}n u \\
(6)\end{array}$ \\
\hline White males & & & & & & \\
$16-19$ & 0.0374 & 0.1205 & 0.3016 & 0.3295 & 0.1543 & 0.0625 \\
$20-24$ & 0.0245 & 0.0381 & 0.3623 & 0.1791 & 0.1949 & 0.0610 \\
$25-59$ & 0.0086 & 0.0037 & 0.3546 & 0.1023 & 0.0795 & 0.0382 \\
White females & & & & & & \\
$16-19$ & 0.0272 & 0.1486 & 0.3065 & 0.3373 & 0.1002 & 0.0519 \\
$20-24$ & 0.0155 & 0.0537 & 0.3903 & 0.1718 & 0.0533 & 0.0331 \\
$25-59$ & 0.0087 & 0.0476 & 0.2733 & 0.2939 & 0.0432 & 0.0124 \\
Nonwhite males & & & & & & \\
$16-19$ & 0.0604 & 0.1551 & 0.2245 & 0.3254 & 0.1067 & 0.0902 \\
$20-24$ & 0.0272 & 0.0328 & 0.2483 & 0.1089 & 0.1238 & 0.0890 \\
$25-59$ & 0.0146 & 0.0105 & 0.3163 & 0.1258 & 0.1087 & 0.0337 \\
Nonwhite females & & & & & & \\
$16-19$ & 0.0464 & 0.1984 & 0.1723 & 0.3562 & 0.0607 & 0.0734 \\
$20-24$ & 0.0239 & 0.0586 & 0.1732 & 0.2754 & 0.0632 & 0.0589 \\
25-59 & 0.0124 & 0.0427 & 0.2264 & 0.3369 & 0.0541 & 0.0314 \\
\hline
\end{tabular}

Source: Derived from official Current Population Survey data from U.S. Bureau of the Census, adjusted for rotation-group bias, as described in the text.

a. $e u=$ from employment to unemployment

$e n=$ from employment to not in the labor force

$u e=$ from unemployment to employment

$u n=$ from unemployment to not in the labor force

$n e=$ from not in the labor force to employment

$n u=$ from not in the labor force to unemployment.

The transition rates are averaged over time so that comparisons among demographic groups can be easily made. Most of the relationships fit within accepted concepts of the labor market.

Age. Within each race-sex group, unemployment rates fall dramatically with advancing maturity. Most flow probabilities that reflect a change in state decline with age, especially the probabilities of leaving employment, $e u$ and en (table 1, columns 1 and 2). School requirements and weak labor-force attachment yield high rates of flow in and out of the labor force, $u n$ and $n u$ (table 1, columns 4 and 6), for teenagers, but these flows decline for those in their twenties. For women, the un flow probability increases again in mature years, possibly because of the demands of motherhood. The reemployment flow, ue (column 3), expands as age improves employability, except in the case of white women, for whom the 
Table 2. Probability of Successful Labor-Force Entry, Participation and Unemployment Rates, and Frequency and Duration of Spells of Unemployment, by Race, Sex, and Age, Monthly Average, 1967-73

\begin{tabular}{|c|c|c|c|c|c|c|}
\hline \multirow[b]{3}{*}{$\begin{array}{l}\text { Race, sex, } \\
\text { and age }\end{array}$} & \multirow{3}{*}{$\begin{array}{c}\text { Probability } \\
\text { of } \\
\text { successful } \\
\text { labor- } \\
\text { force } \\
\text { entry } \\
\text { pnes }\end{array}$} & \multirow{3}{*}{$\begin{array}{c}\text { Partici- } \\
\text { pation } \\
\text { rate } \\
\text { (percent } \\
\text { of } \\
\text { labor } \\
\text { force) }\end{array}$} & & & \multicolumn{2}{|c|}{ Spells of unemployment } \\
\hline & & & \multicolumn{2}{|c|}{$\begin{array}{c}\text { Unemployment } \\
\text { rate } \\
\text { (percent) }\end{array}$} & \multirow{2}{*}{$\begin{array}{c}\text { Frequency } \\
\text { s } \\
\text { (percent } \\
\text { of labor } \\
\text { force per } \\
\text { month) }\end{array}$} & \multirow{2}{*}{$\begin{array}{c}\text { Duration } \\
D \\
\text { (weeks) }\end{array}$} \\
\hline & & & $\begin{array}{l}\text { Calcu- } \\
\text { lated }^{\mathrm{b}}\end{array}$ & Actual & & \\
\hline \multicolumn{7}{|l|}{ White males } \\
\hline $16-19$ & 0.7118 & 58.4 & 11.9 & 12.4 & 7.51 & 6.81 \\
\hline $20-24$ & 0.7615 & 83.7 & 6.3 & 6.7 & 3.41 & 7.94 \\
\hline $25-59$ & 0.6752 & 95.3 & 2.3 & 2.3 & 1.05 & 9.41 \\
\hline \multicolumn{7}{|l|}{ White females } \\
\hline $16-19$ & 0.6586 & 46.1 & 12.9 & 13.0 & 8.31 & 6.68 \\
\hline $20-24$ & 0.6173 & 57.5 & 6.8 & 6.9 & 3.82 & 7.65 \\
\hline $25-59$ & 0.7773 & 48.6 & 3.7 & 3.8 & 2.10 & 7.58 \\
\hline \multicolumn{7}{|l|}{ Nonwhite males } \\
\hline $16-19$ & 0.5418 & 47.9 & 24.7 & 25.5 & 13.58 & 7.82 \\
\hline $20-24$ & 0.5817 & 83.3 & 11.6 & 11.8 & 4.14 & 12.04 \\
\hline $25-59$ & 0.7631 & 90.6 & 4.0 & 4.2 & 1.77 & 9.73 \\
\hline \multicolumn{7}{|c|}{ Nonwhite females } \\
\hline $16-19$ & 0.4523 & 33.9 & 31.7 & 32.5 & 16.75 & 8.14 \\
\hline $20-24$ & 0.5175 & 57.4 & 14.2 & 15.0 & 6.37 & 9.59 \\
\hline $25-59$ & 0.6326 & 58.6 & 6.0 & 6.1 & 3.38 & 7.63 \\
\hline
\end{tabular}

Source: Same as table 1.

a. pne = probability of getting a job this month on entering the labor force.

b. Calculated from text equation 7 using the flow rates from table 1 .

tendency to drop out dominates, and for white males over 25 , for whom it remains at roughly the same high level.

Race. As is well known, unemployment rates for nonwhites are about twice as high as those for whites, even after disaggregation by age and sex. Nonwhites have much higher rates of flow out of employment, eu and en, and much lower flow rates into employment, ue. Except for males aged 25 to 59, the proportion of nonwhites who enter the labor force with a job, pne, is much smaller than that for whites (table 2).

Sex. After disaggregation by age and race, unemployment rates' for women are only slightly higher than those for men, except in the case of older workers. The similarity hides substantially different but partially off- 
setting flow rates. A surprise is that rates of flow into unemployment from employment $(e u)$ and from out of the labor force $(n u)$ are generally smaller for women than for men (table 1, columns 1 and 6). Expressed as a proportion of the labor force, women still have more spells of unemployment than men (table 2) because women are more likely than men to be in the nonparticipation state, which, proportionally, precedes more unemployment spells than does the employment state. The duration of unemployment (also shown in table 2) is actually shorter for women than it is for men: the sum of the rates of flow out of unemployment $(u e+u n)$ (table 1) is greater for women than for men, as is the total rate of flow out of employment $(e u+e n)$, due to the heavy rate of flow out of the labor force (en). A smaller proportion of female than of male entrants into the labor force find a job (pne), except in the case of mature whites.

\section{SPELLS AND DURATION OF UNEMPLOYMENT}

Despite the complications of all of the new flows that have been introduced, the unemployment rate still can be decomposed into the product of the frequency of spells of unemployment $(s)$ and the expected duration of unemployment $(D)$. In a steady state the flows into unemployment, or "spells of unemployment," are equal to the flows out of unemployment. Written as a fraction of the labor force $(L)$, these flows out of unemployment are

$$
s=\frac{U(u e+u n)}{L} .
$$

Since $U / L$ is the unemployment rate, $u$, and $u e+u n$ is the reciprocal of the expected duration of unemployment,

$$
s=u\left(\frac{1}{D}\right)
$$

Rearranging reveals the familiar relation once again:

$$
u=s D \text {. }
$$

The order of the frequencies of spells shown in table 2 is almost exactly the same as the order of the unemployment rates: young people, nonwhites, and women always have more frequent spells of unemployment than more mature workers, whites, and men, respectively. The durations are not so widely different as the frequencies of unemployment, and the 
differences are less consistent. Teenagers and women average shorter spells than more mature workers and men, but not enough shorter to compensate for the more frequent spells they experience. Nonwhites, however, have longer as well as more frequent spells of unemployment.

More than this simple description is not permitted by the breakdown into spells and duration. Each of these two parts is the result of many flow probabilities. For example, the frequency of spells of unemployment depends not only upon the rates of flow out of employment and the flow into participation in the labor force, but also upon the relative sizes of those two states, which are determined by all of the other flow rates. As an analytic tool, therefore, the decomposition of unemployment into spells and duration is only a starting point.

\section{The Impact of Flows on the Unemployment Rate}

The precision of this analysis can be improved by clarifying the objective. For example, employed white females aged 20 to 24 have a 0.007 greater chance of separating from their jobs to become unemployed than do older white females, but also a 0.117 better chance of reemployment (table 1, columns 1 and 3). How do these differences net out? The answer depends upon the levels of the other flow rates: There are more employed than unemployed white females, so that a difference in rates of flow from employment will have more impact than one of the same size from unemployment. The relative sizes of the stocks are in turn determined by the flow rates.

Equation 7 describes the relationship between the unemployment rate and its component flows, so that the differences between flow rates can be judged by the increment they contribute to the unemployment rate. The formula for this purpose is the familiar "total differential" from elementary calculus:

$$
d u=\sum_{i} \frac{\partial u}{\partial p_{i}} d p_{i},
$$

where $u$ is again the unemployment rate, and $p_{i}$ is the $i$ th flow rate. The idea is to break the total difference between the unemployment rates of two demographic groups into the sum of partial differences, $\left(\partial u / \partial p_{i}\right) \Delta p_{i}$, by multiplying the differences in flow rates by the partial derivatives calcu- 
lated from equation 7 . The $i$ th partial difference represents the amount by which the unemployment rates of the two groups would differ if all of the flow rates except the $i$ th were the same in the two groups. Details of this calculation are given in the appendix.

\section{EMPIRICAL ANALYSIS}

Table 3 presents an example of the calculation of the partial differences of unemployment rates using equation 11 . According to these calculations, employed nonwhite teenage males had a 0.0230 greater chance of becoming unemployed than employed white teenage males (row 1); and an increase of 1 percentage point in $e u$ will raise the unemployment rate by 1.433 percentage points (row 2). Multiplying these together gives a partial difference in unemployment rates due to higher rate of flow from employment into unemployment of 3.3 percentage points (row 3). The other columns report the same calculation for the other flows. The sum of all these partial differences is the total difference in unemployment rates, 12.8 percentage points. (The nonwhite rate is 24.7 points while the white rate is only 11.9 points.) Most of the difference between whites and nonwhites is due to the two probabilities $e u$ and pne. The employed nonwhites are much more likely to become unemployed, accounting for 3.3 percentage points of the difference, and when they enter the labor force they are much more likely to remain unemployed, accounting for a further 5.1 percentage points of the difference.

\section{Analysis by Demographic Groups}

Table 4 presents the partial differences in unemployment rates for pairwise comparisons of demographic groups. The comparisons are arranged to isolate a single demographic characteristic, with all other demographic factors held constant.

\section{SEX DIFFERENCES IN LABOR-MARKET EXPERIENCE}

The comparisons indicate that the high rate at which employed women leave the labor force (en) (table 4, column 2) is the main factor in the higher unemployment rates they experience. It accounts for 2.1 percentage 


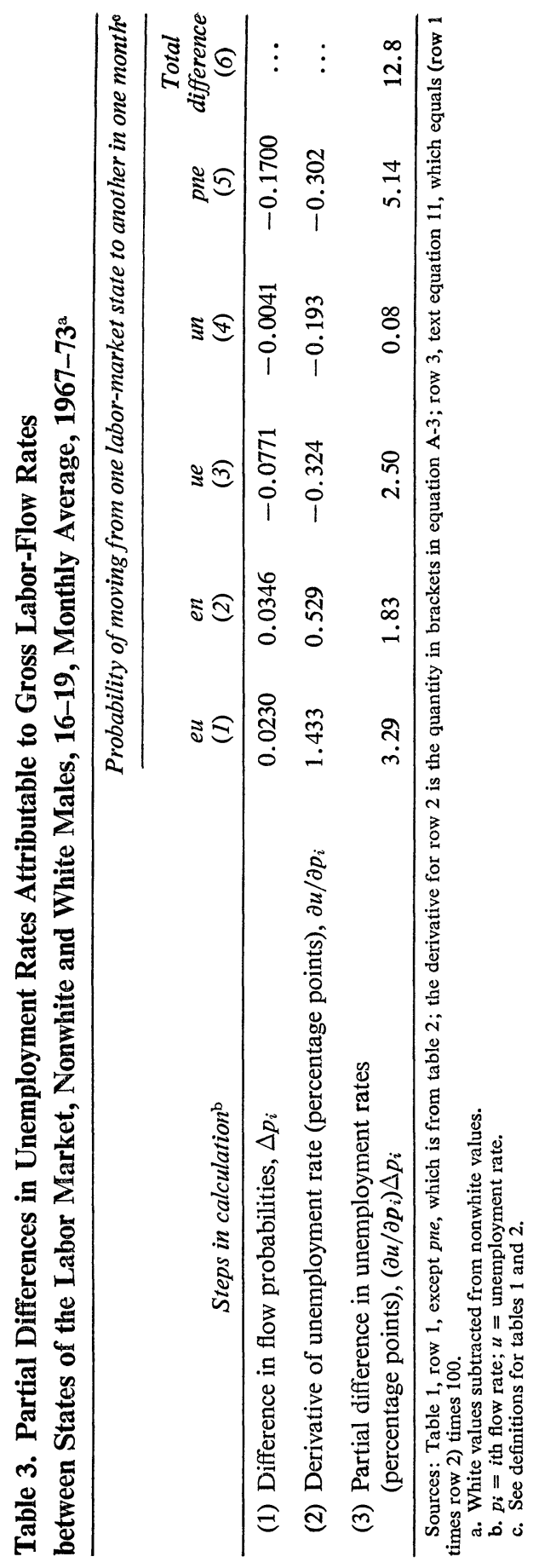


Table 4. Partial Differences in Unemployment Rates Attributable to Gross Labor-Flow Rates between States of the Labor Market, by Race, Age, and Sex, Average, 1967-73

Percentage points of unemployment rate

\begin{tabular}{|c|c|c|c|c|c|c|}
\hline \multirow[b]{2}{*}{$\begin{array}{l}\text { Race, age, } \\
\text { and sex }\end{array}$} & \multicolumn{6}{|c|}{$\begin{array}{l}\text { Probability of moving from one labor-market state } \\
\text { to another in one mont } h^{\mathrm{a}}\end{array}$} \\
\hline & $\stackrel{e u}{(1)}$ & $\begin{array}{l}\text { en } \\
(2)\end{array}$ & $\begin{array}{l}u e \\
(3)\end{array}$ & $\begin{array}{l}u n \\
(4)\end{array}$ & $\begin{array}{c}\text { pne } \\
(5)\end{array}$ & $\begin{array}{l}\text { Total } \\
\text { difference } \\
\text { (०) }\end{array}$ \\
\hline & \multicolumn{6}{|c|}{ Partial differences by sex: females minus males } \\
\hline White & & & & & & \\
\hline $16-19$ & -1.47 & 1.27 & -0.10 & -0.11 & 1.39 & 0.99 \\
\hline $20-24$ & -1.58 & 0.85 & -0.34 & 0.06 & 1.47 & 0.46 \\
\hline $25-59$ & 0.00 & 2.46 & 0.51 & -0.88 & -0.66 & 1.44 \\
\hline \multicolumn{7}{|l|}{ Nonwhite } \\
\hline 16-19 & -1.97 & 3.05 & 2.89 & -0.84 & 3.91 & 7.05 \\
\hline $20-24$ & -0.79 & 2.80 & 2.68 & -3.25 & 1.15 & 2.58 \\
\hline $25-59$ & -0.47 & 2.04 & 1.00 & -1.61 & 1.07 & 2.03 \\
\hline Weighted average - & -0.39 & 2.13 & 0.45 & -0.80 & 0.01 & 1.41 \\
\hline & \multicolumn{6}{|c|}{ Partial differences by age: 16-19 group minus $25-59$ group } \\
\hline White & & & & & & \\
\hline Males & 5.16 & 6.43 & 0.71 & -2.16 & -0.53 & 9.61 \\
\hline Females & 2.99 & 4.62 & -0.51 & -0.45 & 2.51 & 9.16 \\
\hline \multicolumn{7}{|l|}{ Nonwhite } \\
\hline Males & 8.33 & 8.52 & 2.57 & -3.23 & 4.51 & 20.70 \\
\hline Females & 5.58 & 11.75 & 2.38 & -0.40 & 6.42 & 25.72 \\
\hline \multirow[t]{2}{*}{ Weighted average } & 4.68 & 6.23 & 0.52 & -1.59 & 1.11 & 10.95 \\
\hline & \multicolumn{6}{|c|}{ Partial differences by race: nonwhite minus white } \\
\hline Male & & & & & & \\
\hline $16-19$ & 3.29 & 1.83 & 2.50 & 0.08 & 5.14 & 12.83 \\
\hline $20-24$ & 0.56 & -0.36 & 2.36 & 0.93 & 1.81 & 5.30 \\
\hline $25-59$ & 1.37 & 0.43 & 0.28 & -0.12 & -0.21 & 1.74 \\
\hline \multicolumn{7}{|l|}{ Female } \\
\hline 16-19 & 2.71 & 3.07 & 5.52 & -0.40 & 7.98 & 18.89 \\
\hline $20-24$ & 1.67 & 0.42 & 4.98 & -1.31 & 1.66 & 7.42 \\
\hline $25--59$ & 0.72 & -0.27 & 0.45 & -0.29 & 1.70 & 2.32 \\
\hline Weighted average & 1.31 & 0.37 & 1.14 & -0.16 & 1.24 & 3.90 \\
\hline
\end{tabular}

Source: Derived by the method used for table 3, row 3 .

a. See definitions in tables 1 and 2. 
points of the difference in unemployment rates between men and womeneven more than the actual difference of only 1.4 percentage points (column 6). None of the other flow rates adds much to women's unemployment rates. In fact, the lower flow rate of employed women into unemployment (eucolumn 1) actually helps cut their unemployment rates relative to men's. Similarly, the high rate of flow out of the labor force from unemployment (un-column 4) lowers unemployment rates for women. This last effect is not necessarily desirable and may represent discouraged workers.

There are at least two interpretations of the large flow rate en for females. One is that women decide to leave the labor force for such noneconomic reasons as their desire to devote themselves to child-rearing or homemaking. This could be called a "participation instability" explanation of female unemployment. The other interpretation is that, just like men, women lose or leave their jobs for economic reasons such as layoffs, but a larger fraction of women become discouraged and drop out of the labor force, becoming part of $E N$ rather than $E U$. Viewed this way, the participation instability (en) of women cuts the unemployment-rate differential, because it reduces the flow rate $e u$, which has an impact on the unemployment rate three times greater than en. Supporting this interpretation for at least some dropouts is the fact that $e u$ flow rates are lower for women than for men.

This issue cannot be resolved here, because doing so requires separating the $E N$ flows into job losers and job leavers, and distinguishing economic from noneconomic reasons for dropping out. But the fact that the en flow rate does not increase during recession suggests that it does not depend primarily on economic factors. The cyclical analysis below shows that, except for whites aged 20 to 24, the en flow rates for women fall during recession. Most likely, then, a flow of employed women out of the labor force for noneconomic reasons is the primary cause of high unemployment rates for females.

It may appear puzzling that a flow that has no initial impact on the pool of the unemployed itself, but only reduces the size of the labor force, could be so powerful in determining the unemployment rate for women. The explanation lies in the indirect augmentation of unemployment flows captured in steady-state equation 5. Total flows into unemployment from employment are increased by the fraction of dropouts who reenter the labor force unsuccessfully and become unemployed. The workers who 
enter the labor force at any one time are not the same workers who leave it, but in a steady state the more there are leaving the labor force, the more there are undertaking the risky venture of entering. Since $n u$ is much higher than $e u$ for all demographic groups, unemployment is the much more likely lot of the worker reentering the labor force than it is of one already employed. Because they so frequently drop out of the labor force, women are more frequently in the difficult position of seeking a job on reentering it.

The aggregate unemployment-rate differential discussed is dominated by its largest component, the differential for mature white workers. The differentials for other groups mostly reemphasize the importance of the high en flow for women, but also suggest a particularly poor rate of successful labor-market entry (pne) for all except mature women. Nonwhite teenage females face particularly discouraging job prospects upon entering the labor force, and this phenomenon is the main cause of their high unemployment rate.

\section{AGE DIFFERENCES IN LABOR-MARKET EXPERIENCE}

The two rates of flow out of employment clearly dominate the unemployment rate for teenagers. Between them they account for virtually all of the difference (11 percentage points) between teenage and mature workers (table 4, middle section, column 6). The rate of flow out of the labor force (en) adds 6.2 percentage points to the unemployment rate, slightly more than the rate into unemployment (eu), which adds 4.7 percentage points. Once again cyclical evidence below argues for the noneconomic nature of the en flow, because this flow always falls slightly in recession; if it were responsive more to economic factors, it would increase with the employment cutbacks. But the big role played by the eu flow rate definitely introduces an economic factor into the unemployment picture of teenagers. The size of this flow indicates either that teenagers get laid off very frequently from their jobs or that they quit more often than mature workers, and that a sizable proportion does not leave the labor force after separation.

\section{RACIAL DIFFERENCES IN LABOR-MARKET EXPERIENCE}

In comparisons between whites and nonwhites, the differences in unemployment rates are spread more evenly across the flow rates than they are 
in the other comparisons. Each flow adds a small increment to the unemployment rate of nonwhite workers. And the results are not as consistent as they are for the other comparisons. For example, the interracial comparison between males aged 20 to 24 produces unique results. Nevertheless, the high flow rate of nonwhites from jobs into unemployment (eu) can be seen as the main factor in their unemployment rates, adding 1.3 percentage points to the black-white differential (table 4, last section). Only slightly less significant is the poor job prospects nonwhites face when entering the labor force (pne), which add another 1.2 percentage points. The slim chances of moving from unemployment to a job (ue) adds another 1.1 percentage points. But employed nonwhites show about the same tendency as their white counterparts to drop out of the labor force (en), unlike the wide differences between women and men, and between teenagers and mature workers.

\section{CONCLUSIONS ON UNEMPLOYMENT-RATE DIFFERENTIALS}

The comparisons just discussed establish employment separations of one kind or another as the common factor linking unemployment rates among teenagers, nonwhites, and women. Employed women drop out of the labor force (en), employed nonwhites become unemployed (eu), and employed teenagers do both in copious flows. The difficulty of both unemployed workers and labor-force entrants in finding a job (ue and pne, respectively) contributes substantially to unemployment rates among nonwhites. Except for this group, the probabilities of leaving unemployment (ue and un) play only minor roles.

In interpreting these conclusions, one must remember that the gross-flow data do not distinguish between a continuous period of employment in a single job and one in several jobs, so long as no spells of unemployment or nonparticipation intervene. The term "employment separation" applies only to those who spend time in nonemployment activities between employment periods.

These findings do not really establish the reasons for chronically high unemployment rates, because the reasons lie behind the flows. But they do help direct the search for reasons and solutions to particular areas of the labor market. An effort toward further narrowing the range of reasons appears in later sections of this paper. 


\section{Cyclical Changes in Flows}

When the labor market softens, labor-flow rates change in predictable ways. During a downswing, average rates of flow into unemployment rise and those out of unemployment fall. The changes in these flows increase the unemployment rate.

But the changes are not the same for each demographic group. In order to compare these movements, I have averaged the flow rates in tight and loose labor markets for each demographic group. Each month in the sample (1967 to 1973) was first classified as tight or loose depending upon whether the aggregate unemployment rate was below or above its mean, respectively. Then each of the flow rates in each of the demographic groups was averaged separately in loose and tight samples. Table 5 presents these averages.

The sample means, both loose and tight, approximate a steady state, because the months in which the unemployment rate was rising are balanced by the months in which it was falling. Therefore, the same steadystate analysis can be applied to every sample and the differences between them decomposed in the same way as those between demographic groups. In effect, equation 7 is now applied to the difference in unemployment rates resulting from weak labor demand to establish the contributions of each of the flow rates to the total difference in unemployment. The whole process is repeated for all the demographic groups.

Table 6 presents the resulting partial differences in unemployment rates. It shows that cyclical differences in unemployment rates arise primarily from difficulties experienced in finding jobs rather than from employment separations.

In the total labor force, averaged from all the groups using labor-force weights, the decreased chance that an unemployed worker has of getting a job $(u e)$ dominates the cyclical swing in unemployment rates. The flow rate $u e$ declines so much that 0.9 percentage point of the total increase of 1.7 percentage points in the unemployment rate can be attributed to it. ${ }^{9}$ Much

9. Perry arrives at a similar conclusion, with lengthened duration of unemployment accounting for 23 to 42 percent of increases in the unemployment rate between 4 and 5 percent. See Perry, "Unemployment Flows," p. 259. Since unemployment duration includes the effects of both $u e$ and $u n$, the figure from the present calculation is $0.85 / 1.74$, or 49 percent. 
Table 5. Gross Labor-Flow Rates between States of the Labor Market, in Tight and Loose Labor Markets, by Race, Sex, and Age, Monthly Average, 1967-73

Probability of individual in origin state in one month being in destination state in the second month, except as noted

\begin{tabular}{|c|c|c|c|c|c|c|c|}
\hline \multirow{2}{*}{$\begin{array}{l}\text { Race, sex, } \\
\text { and age }\end{array}$} & \multirow{2}{*}{$\begin{array}{l}\text { Level of } \\
\text { unemploy- } \\
\text { ment rate }\end{array}$} & \multicolumn{5}{|c|}{$\begin{array}{c}\text { Probability of moving from one labor-market } \\
\text { state to another in one mont } h^{\mathrm{a}}\end{array}$} & \multirow{2}{*}{$\begin{array}{l}\text { Calculated } \\
\text { unemploy } \\
\text { ment rate } \\
\text { (percent) }\end{array}$} \\
\hline & & $e u$ & en & ue & un & pne & \\
\hline \multicolumn{8}{|l|}{ White males } \\
\hline \multirow[t]{2}{*}{$16-19$} & Low & 0.0379 & 0.1259 & 0.3303 & 0.3694 & 0.7487 & 10.3 \\
\hline & High & 0.0369 & 0.1155 & 0.2745 & 0.2916 & 0.6803 & 13.5 \\
\hline \multirow[t]{2}{*}{$20-24$} & Low & 0.0226 & 0.0397 & 0.4476 & 0.1842 & 0.8124 & 4.8 \\
\hline & High & 0.0262 & 0.0366 & 0.2813 & 0.1742 & 0.7211 & 8.2 \\
\hline \multirow[t]{2}{*}{$25-59$} & Low & 0.0068 & 0.0040 & 0.3753 & 0.1097 & 0.7393 & 1.7 \\
\hline & High & 0.0102 & 0.0035 & 0.3349 & 0.0953 & 0.6048 & 2.9 \\
\hline \multicolumn{8}{|c|}{ White females } \\
\hline \multirow[t]{2}{*}{$16-19$} & Low & 0.0263 & 0.1493 & 0.3281 & 0.3444 & 0.6818 & 11.6 \\
\hline & High & 0.0281 & 0.1479 & 0.2860 & 0.3306 & 0.6400 & 14.0 \\
\hline \multirow[t]{2}{*}{$20-24$} & Low & 0.0179 & 0.0504 & 0.4335 & 0.1855 & 0.6769 & 5.8 \\
\hline & High & 0.0132 & 0.0568 & 0.3492 & 0.1587 & 0.5738 & 7.8 \\
\hline \multirow[t]{2}{*}{$25-59$} & Low & 0.0074 & 0.0502 & 0.3624 & 0.2526 & 0.7892 & 3.1 \\
\hline & High & 0.0098 & 0.0450 & 0.1887 & 0.3332 & 0.7666 & 4.4 \\
\hline \multicolumn{8}{|c|}{ Nonwhite males } \\
\hline \multirow[t]{2}{*}{$16-19$} & Low & 0.0461 & 0.1588 & 0.2685 & 0.3046 & 0.5385 & 21.6 \\
\hline & High & 0.0739 & 0.1516 & 0.1828 & 0.3452 & 0.5450 & 27.8 \\
\hline \multirow[t]{2}{*}{$20-24$} & Low & 0.0181 & 0.0286 & 0.2548 & 0.1050 & 0.5979 & 8.5 \\
\hline & High & 0.0358 & 0.0368 & 0.2421 & 0.1125 & 0.5681 & 14.4 \\
\hline \multirow[t]{2}{*}{$25-59$} & Low & 0.0139 & 0.0109 & 0.3752 & 0.1165 & 0.8655 & 3.1 \\
\hline & High & 0.0153 & 0.0101 & 0.2604 & 0.1346 & 0.6671 & 5.1 \\
\hline \multicolumn{8}{|c|}{ Nonwhite females } \\
\hline \multirow[t]{2}{*}{$16-19$} & Low & 0.0390 & 0.2064 & 0.2043 & 0.3561 & 0.4748 & 28.3 \\
\hline & High & 0.0534 & 0.1909 & 0.1419 & 0.3563 & 0.4322 & 35.4 \\
\hline \multirow[t]{2}{*}{$20-24$} & Low & 0.0320 & 0.0696 & 0.2503 & 0.2807 & 0.6069 & 12.4 \\
\hline & High & 0.0163 & 0.0481 & 0.0999 & 0.2704 & 0.4219 & 17.1 \\
\hline \multirow[t]{2}{*}{$25-59$} & Low & 0.0136 & 0.0481 & 0.2676 & 0.3509 & 0.6937 & 5.2 \\
\hline & High & 0.0113 & 0.0377 & 0.1872 & 0.3236 & 0.5668 & 6.9 \\
\hline
\end{tabular}

Source: See table 1.

a. See tables 1 and 2 for definitions. 
Table 6. Partial Difference in Cyclical Unemployment Rates Attributable to Changes in Gross Labor-Flow Rates, by Race, Sex, and Age, Monthly Average, 1967-73

Percentage points

Probability of moving from one labor-market state to another in one month ${ }^{\mathrm{a}}$

\begin{tabular}{|c|c|c|c|c|c|c|}
\hline \multirow{2}{*}{$\begin{array}{l}\text { Race, sex, } \\
\text { and age }\end{array}$} & \\
\hline & $e u$ & en & ue & un & pne & Total \\
\hline \multicolumn{7}{|l|}{ White males } \\
\hline $16-19$ & -0.14 & -0.43 & 1.09 & 1.08 & 1.63 & 3.22 \\
\hline $20-24$ & 0.63 & -0.13 & 2.02 & 0.09 & 0.81 & 3.42 \\
\hline $25-59$ & 0.77 & -0.04 & 0.21 & 0.05 & 0.19 & 1.18 \\
\hline \multicolumn{7}{|l|}{ White females } \\
\hline $16-19$ & 0.26 & -0.07 & 0.89 & 0.19 & 1.19 & 2.46 \\
\hline $20-24$ & -0.82 & 0.42 & 1.07 & 0.21 & 1.19 & 2.07 \\
\hline $25-59$ & 0.44 & -0.21 & 1.24 & -0.45 & 0.25 & 1.27 \\
\hline \multicolumn{7}{|l|}{ Nonwhite males } \\
\hline $16-19$ & 3.93 & -0.47 & 3.98 & -1.02 & -0.24 & 6.17 \\
\hline $20-24$ & 4.45 & 0.86 & 0.41 & -0.14 & 0.35 & 5.93 \\
\hline $25-59$ & 0.31 & -0.04 & 1.09 & -0.13 & 0.70 & 1.93 \\
\hline \multicolumn{7}{|l|}{ Nonwhite females } \\
\hline $16-19$ & 2.01 & -1.18 & 4.06 & -0.01 & 2.17 & 7.04 \\
\hline $20-24$ & -3.62 & -2.39 & 5.98 & 0.20 & 4.55 & 4.73 \\
\hline $25-59$ & -0.46 & -0.77 & 1.05 & 0.22 & 1.65 & 1.68 \\
\hline \multicolumn{7}{|c|}{ Weighted averages } \\
\hline Whites & 0.50 & -0.08 & 0.76 & -0.01 & 0.44 & 1.60 \\
\hline Nonwhites & 0.39 & -0.45 & 1.66 & -0.03 & 1.27 & 2.84 \\
\hline Males & 0.73 & -0.07 & 0.59 & 0.11 & 0.41 & 1.77 \\
\hline Females & 0.08 & -0.22 & 1.30 & -0.20 & 0.73 & 1.69 \\
\hline $16-19$ & 0.38 & -0.32 & 1.34 & 0.54 & 1.36 & 3.29 \\
\hline $20-24$ & 0.07 & 0.02 & 1.77 & 0.13 & 1.14 & 3.14 \\
\hline $25-59$ & 0.58 & -0.13 & 0.63 & -0.11 & 0.31 & 1.28 \\
\hline All persons & 0.48 & -0.13 & 0.86 & -0.01 & 0.53 & 1.74 \\
\hline
\end{tabular}

Source: Derived from text equation 7, using basic data as in table 1 .

a. See tables 1 and 2 for definitions.

b. Labor-force weights.

of the remaining deterioration in the unemployment rate can be assigned to labor-force entrants, whose lowered chance of finding a job (pne) raises the unemployment rate 0.5 percentage point. The enlarged flow of employed workers into unemployment adds another 0.5 percentage point to the overall rate. Altogether, that means 1.4 percentage points of the cyclical 
differential are attributable to the trouble unemployed workers and new entrants have in finding a job, but only 0.5 percentage point is due to employment separations.

The number of employment separations does not rise drastically during recession because heavier layoffs are partially offset by reduced quits. Timeseries analysis of turnover rates in manufacturing show layoffs increasing during periods of high unemployment, while quits fall markedly as workers do what they can to avoid unemployment. ${ }^{10}$

In almost every group, the deteriorating probability that unemployed workers will find a job $(u e)$ is the main single factor raising unemployment rates. An interesting reversal occurs in the relative importance of $e u$ and pne across demographic groups. Among the "secondary" labor-force groups-nonwhites, women, and teenagers-failure to achieve successful labor-force entry (pne), rather than employment instability $(e u)$, is the major factor increasing unemployment during recessions. The "primary" groups have exactly the reverse experience: job loss takes a large toll, while the probabilities for labor-force entry change little. One reason for this is simple: rates of nonparticipation in the labor force are higher for the secondary groups, so any deterioration in the chance of successful laborforce entry plays a big role. Similarly, the primary groups have an increased risk from employment separation because such a large fraction of their population is employed. But compared with other groups, employment outflow rates among mature white males appear to be slightly more sensitive to the business cycle.

The overriding importance of $u e$ and pne shows that cyclical run-ups in unemployment rates stem from a very different set of flows than do enlarged unemployment rates associated with disadvantaged demographic groups. In a recession the problem is finding a job, not just for labor-force entrants but also for job losers and leavers. But the disadvantaged groups in average labor markets primarily have difficulty keeping their jobs, and except for new entrants seem not to have much more difficulty than others do in finding a job.

\section{Determinants of Unemployment Flows from Employment}

Each of the flows in the previous sections could be profitably examined for its underlying causes. But since the flows out of employment are re-

10. Peter S. Barth, “A Time Series Analysis of Layoff Rates," Journal of Human Resources, vol. 6 (Fall 1971), pp. 448-65. 
vealed as the prime cause of high unemployment rates among disadvantaged labor-force groups, those are the most interesting flows.

The data limit an in-depth examination to the rate of flow from employment to unemployment $(\mathrm{eu})$. For nonwhites these flows are by far the main cause of unemployment problems and for teenagers they are a major factor. Little can be learned about female unemployment from this analysis since it is governed by the en flow rate. The data are from individual respondents to the March 1973 Current Population Survey. Three alternative measures are used as dependent variables: $e u$; quits, $Q$; and layoffs, $L$.

The variable $e u$ is an estimate of an employed worker's probability of becoming unemployed, and is derived from householders' responses to the query about their employment in the previous year (1972 in this case). It is equal to the number of spells of unemployment experienced by a worker divided by the number of periods during which the worker could have become unemployed - that is, the number of weeks he was employed during the year. ${ }^{11}$

The variables $Q$ and $L$ divide job separations into voluntary job leaving and involuntary job losing, and reflect information that respondents give about their current (March 1973) work status. If a worker has been unemployed for less than a few weeks, he has recently begun an unemployment spell. The number of such people divided by the number of employed workers and of newly unemployed workers is a measure of the probability of becoming unemployed during the few-week interval. Therefore, a binary variable coded 1 for the newly unemployed and 0 for the employed will have a mean value of that same probability and can be used as a dependent variable in regressions. The maximum duration for a "new" spell of unemployment is three weeks at the time of survey. This is a pragmatic compromise between solutions to two competing data problems: a shorter limit is theoretically better because it confines the "new" spells to workers who have just become unemployed, but it weakens the analysis by reducing the number of individuals who pass the criterion. A longer limit has the corresponding but opposite problems.

Conveniently, the Current Population Survey also asks the reason for unemployment. Thus, the probability of starting an unemployment spell can be separated into the quit flows $(Q)$ and the layoff flows $(L)$, which may Force."

11. Hall has investigated this probability with earlier data in "Turnover in the Labor 
have different sources. In summary, the variables to measure flow rates from employment to unemployment are coded as shown below:
Variable
Description in universe
eu
Probability of an employed
worker becoming unemployed
Ratio of spells of unemployment in 1972 to weeks of employ- ment in 1972
$Q \quad$ Probability of an employed
1 if new spell of unemployment worker becoming unemployed by quitting in March 1973 and quit job; 0 otherwise
$L \quad$ Probability of an employed 1 if new spell of unemployment worker becoming unemployed in March 1973 and laid off by layoff from job; 0 otherwise

Value for each individual

Each of these dependent variables is regressed ${ }^{12}$ on a wealth of independent variables that describe the personal characteristics of a worker and the characteristics of the job he held. Table 7 presents the coefficients and $t$-statistics from the regressions. The first two columns are the results of the $e u$ regression; the second and third pairs of columns are from the $Q$ and $L$ regressions, respectively. The $e u$ regression has a continuous dependent variable and therefore produces much more solid results than the quit and layoff regressions, in which the dependent variable rarely takes on a nonzero value. Most of the $t$-statistics in the $e u$ regression are significant, while only a few in the quit and layoff regression are, despite 56,000 observations. The $e u$ regressions will not necessarily agree with the quit and layoff regressions because $e u$ measures all of 1972, rather than March 1973 alone. Nevertheless, the regressions fail to agree only in their results for the familyhead variable: being in that position is found to increase transitions into unemployment yet reduce both quits and layoffs. In any case, all three variables are insignificant.

The quit and layoff variables are quite different from the labor-turnover series commonly reported, which is based on establishment data. The variables used in this paper tally a quit or layoff only if the worker becomes unemployed thereafter; by contrast, the establishment variables count a worker as a quit or layoff even if he gets another job immediately or drops out of the labor force. For the purpose of studying unemployment flows,

12. Since the dependent variables are confined to the interval $[0,1]$ a logit method would be more powerful. 
the variables developed here seem preferable, though it would be useful to have the flows of quits and layoffs into all the destination states.

\section{Empirical Results}

In March 1973 the establishment reports put the layoff rate in manufacturing at 0.8 percent while the quit rate was 2.5 percent, ${ }^{13}$ a ratio of 0.3 to 1 . But because most took another job or left the labor force, so few of the job quitters became unemployed that new spells of unemployment among job losers exceeded those among quitters by a ratio of 2.8 to 1 . During the three-week period studied, 6.7 of every 1,000 employed workers were laid off and became unemployed. But the duration of spells of unemployment among leavers was slightly longer than that of spells among losers, for job losers accounted for 37.8 percent of unemployment in March 1973, against 16.8 percent for job quitters, a ratio of 2.25 to 1 .

\section{PERSONAL VARIABLES}

Both a married worker and a worker from a large family are less likely to become unemployed, either by quit or layoff, presumably because of their family responsibilities. Whatever their marital status or family size, workers from metropolitan areas are more likely to become unemployed by either route than those outside; their quit rate is higher perhaps because they have greater options and thus less fear of the consequences. The more educated worker is much less likely to become unemployed, in apparent reflection of his much diminished risk of losing his job. Family position has the expected effect: the household head is most stable, followed by the wife and unrelated individuals. By far the least stable employees are other relatives within the family, mostly children.

The age variables are categorical, having a value of one if the worker is within an indicated age bracket. Since the $e u$ variable includes summer employment, its regression on the age variables shows unemployment flows greatest for teenagers and declining in later years. But the quit and layoff regressions, measuring March, when most teenagers are in school, peak in

13. Data on layoff and quit rates and the contribution to unemployment of job losers and quitters are from Employment and Earnings, vol. 20 (July 1973), p. 121, and ibid. (April 1973), p. 49. The terms "nonwhite" and "black" are used interchangeably in the text discussion below. 


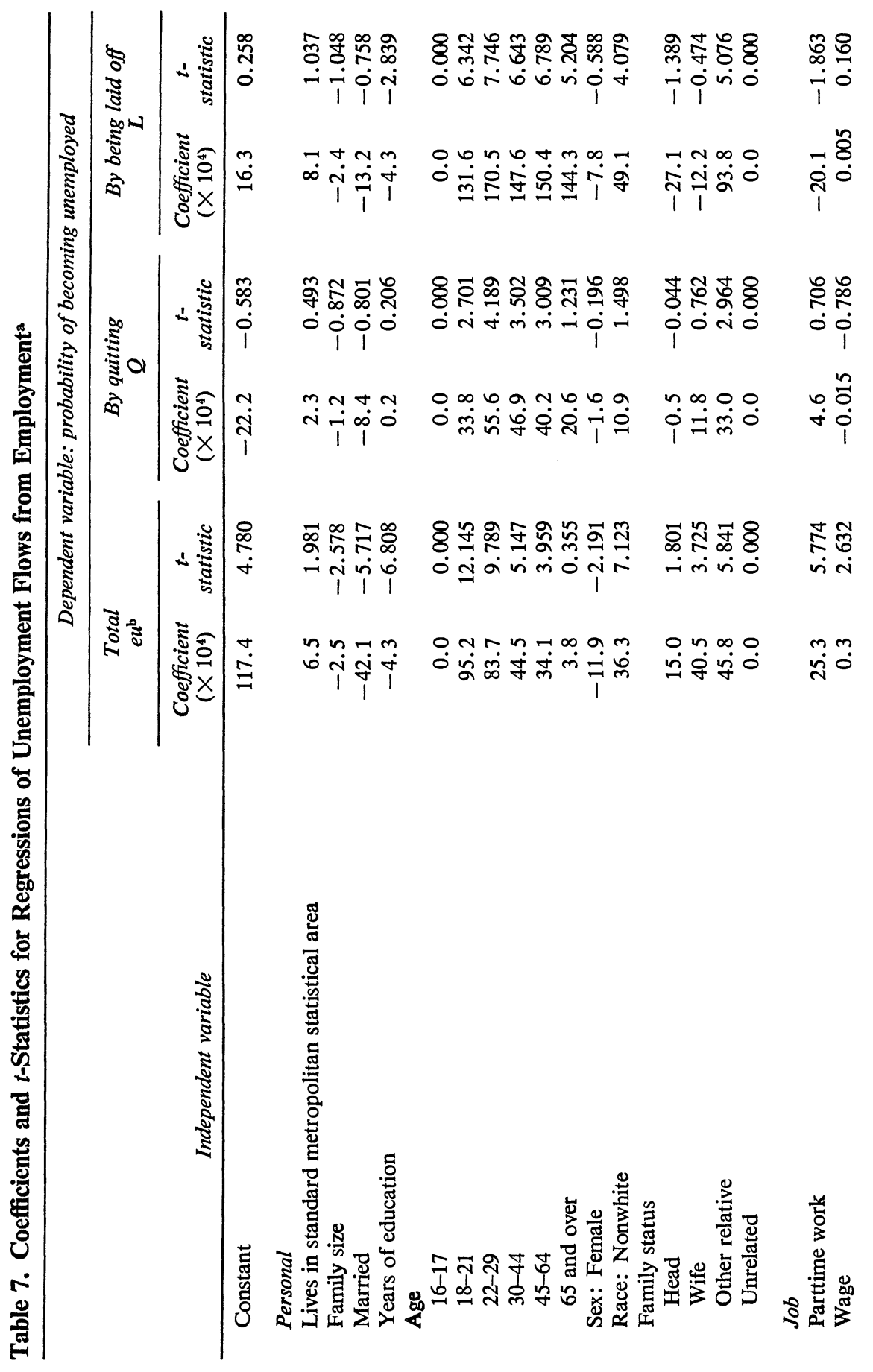




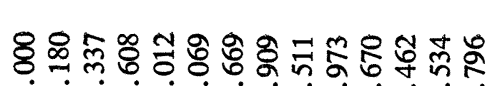
000 iोंगोiी

O-6no

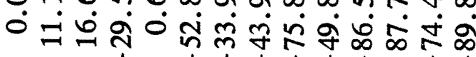

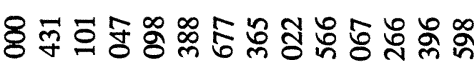

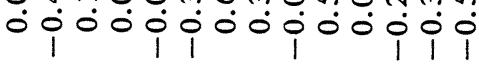

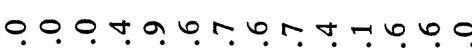

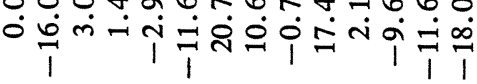

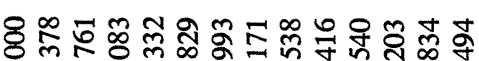

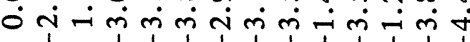

ODNaObarranomm 施它㶽

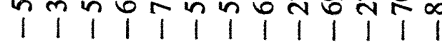

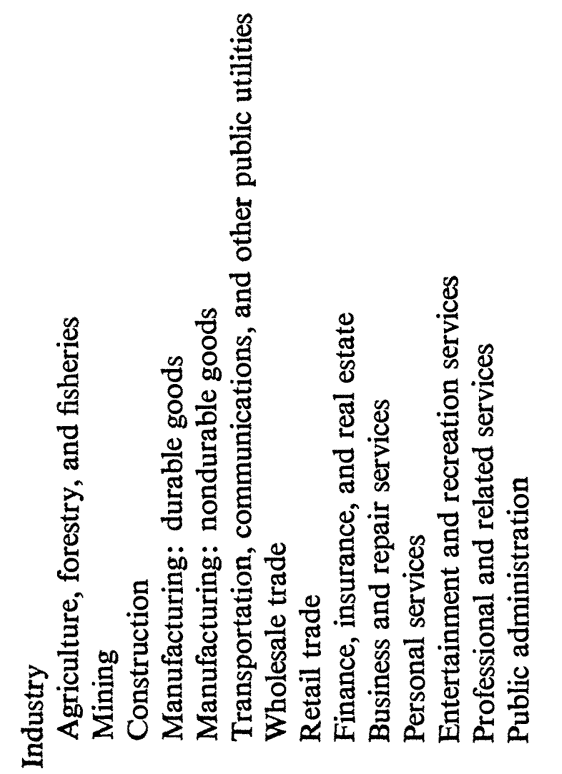

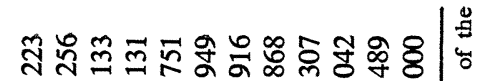
o jo0000-iotio

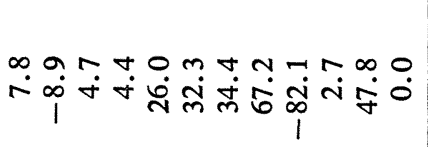

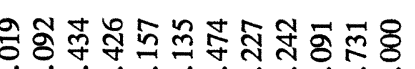
१iी

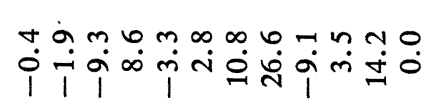

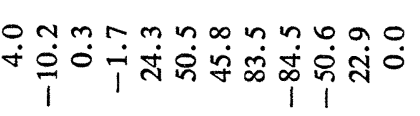

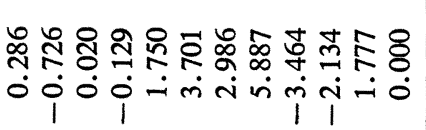


the 22-29 age bracket and then decline as age increases. Quits and layoffs appear to play a significant role in unemployment of youth. Seasonal quits and layoffs are a major factor in teenage unemployment flows.

Employed women become jobless somewhat less frequently than do men, both through layoffs and quits. But the gross-flow analysis indicates that this difference arises because women leave the labor force more often when they separate from a job.

The race variable is crucial, because the gross-flow analysis has already established that the high $e u$ flow rate is the main factor inflating unemployment rates for nonwhites. The microanalysis reveals that employed nonwhites are much more likely to become unemployed than whites even when they are from the same industry and occupation and have the same age and family status as whites. This greater vulnerability reflects primarily the increased risk of layoffs they suffer, although their quit rates are also somewhat higher. But these layoffs and quits do not result exclusively from bad jobs: from the same industry, occupation, and wage group, the nonwhite is much more likely to be laid off and become unemployed. The race coefficients for both the $e u$ and the layoff regressions are positive and highly significant.

\section{JOB VARIABLES}

A higher wage is associated with higher $e u$ turnover, primarily because workers with a high risk of layoff must be compensated with a higher wage. (In these equations, the wage variable is measured as labor income per week worked in 1972.) However, the negative sign of the wage in the quits equation indicates that firms buy lower quit rates with higher wages. Parttime workers are likely to quit their jobs, but have a small chance of being laid off.

The fourteen industries and twelve occupations are dummy variables designed to remove any consistent influence of industry or occupation from the other coefficients. The high-quit industries are wholesale trade, and business and repair services, while public administration has few quits. Entertainment and construction are high-layoff industries, while personal services and public administration are low-layoff industries. Among occupations, farmers and farm managers have both low quits and layoffs, while laborers except those on farms display both high quits and layoffs. 


\section{Bad Jobs and Labor Turnover}

Dual-labor-market theorists often argue that blacks, teenagers, and women get stuck in bad jobs, and that therefore they have high turnover rates and resulting high unemployment rates. The analysis here has established that the high unemployment rates for these groups are due to high flows out of employment. But is it bad jobs that lead to these flows, or is it something more closely connected to personal characteristics? Will a worker from a disadvantaged demographic group be as stable an employee as a mature, white, male head of household in the same job?

The regression shows that bad jobs are not the only cause of high labor turnover, at least insofar as the "bad" jobs can be identified by wage, industry, and occupation. If jobs determined labor turnover, and blacks and youths suffered higher rates of employment outflow only because of their bad jobs, all of the personal variables would have insignificant coefficients. If jobs and personal variables were very highly correlated, so that blacks and youths had only bad jobs while mature whites always had good jobs, both job and personal variables would be insignificant.

That the coefficients of the personal variables are statistically significant does not necessarily mean that these variables account for much of the variation of turnover rates among groups. Variation will be determined not only by the value of the regression coefficients, but also by the variation of the independent variable. A convenient way to measure these together is through an analysis of the variance of the turnover-rate variables explained by the regressions. The incremental contribution of the personal variables to the variation of one of the turnover variables is equal to the explained variation of the dependent variable in a regression on all independent variables less the explained variation in a regression that excludes the personal variables. ${ }^{14}$

Table 8 presents an analysis of the variance of each of the dependent variables. Row 1 lists for each dependent variable the variance explained by all independent variables. Row 2 gives the explained variance from a regression excluding the personal variables. Row 3 , calculated by subtracting row 2 from row 1 , represents the incremental contribution of the personal variables to the explanation of the variance of the dependent variable. Similarly, row 4 gives the explained variance excluding job variables and row 5

14. Henri Theil, Principles of Econometrics (Wiley, 1971), pp. 167-81. 
Table 8. Analysis of Explained Variance in Job-Turnover Flow Rates ${ }^{\mathrm{a}}$

Variation of dependent variable attributable to independent variables

\begin{tabular}{|c|c|c|c|c|}
\hline & \multirow[b]{2}{*}{ Independent variable ${ }^{\mathrm{b}}$} & \multicolumn{3}{|c|}{$\begin{array}{c}\text { Dependent variable: probability of becoming } \\
\text { unemployed from employment }{ }^{\mathrm{b}}\end{array}$} \\
\hline & & $\begin{array}{c}\text { Total } \\
\text { eu }\end{array}$ & $\begin{array}{l}\text { By quitting } \\
Q\end{array}$ & $\begin{array}{l}\text { By being laid off } \\
L\end{array}$ \\
\hline (1) & All independent variables & 2.52 & 0.257 & 2.54 \\
\hline (2) & Excluding personal variables & 1.56 & 0.136 & 1.39 \\
\hline (3) & $\begin{array}{l}\text { Incremental contribution } \\
\text { of personal variables }\end{array}$ & 0.96 & 0.121 & 1.15 \\
\hline (4) & Excluding job variables & 1.64 & 0.176 & 1.70 \\
\hline (5) & $\begin{array}{l}\text { Incremental contribution } \\
\text { of job variables }\end{array}$ & 0.88 & 0.081 & 0.84 \\
\hline (6) & Multicollinearity effect ${ }^{\mathrm{e}}$ & 0.68 & 0.055 & 0.55 \\
\hline
\end{tabular}

Sources: Derived from expression $\Sigma(\hat{e u}-\overline{e u})^{2}$, where $\hat{e u}$ is the predicted value of the dependent variable from a regression on the corresponding independent variables given in the table and $\overline{e u}$ is its mean. The source of the basic data is the same as that for table 7 .

a. Data for $e u$ are for 1972; for $Q$ and $L$, March 1973.

b. See table 7 for descriptions or definitions of the independent and dependent variables.

c. Row 1 minus row 2 .

d. Row 1 minus row 4.

e. Row 1 minus row 3 minus row 5 .

the incremental contribution of the job variables to the explained variance. The remaining variance explained by the independent variables whose origin cannot be assigned to either the job or personal variables because of the correlation between them appears in row 6 . This "multicollinearity effect" is found by subtracting the sum of the incremental contributions from the total variance explained by the regression.

The incremental contribution of the personal variables is always greater than that of the job variables. On this measure the personal variables explain 9 percent more variance in the $e u$ variable, 49 percent more variance in the $Q$ variable, and 37 percent more variance in the $L$ variable than do the job variables. A strong conclusion cannot be drawn, however, because of the large zone of indeterminacy created by the correlation of job and personal variables. If all of the unassignable explained variance, the multicollinearity effect, were attributed to the job variables, these variables would tally more explained variance than the personal variables. While it cannot be said that the personal variables explain more variance than the job variables, they do explain at least 38,47 , and 45 percent of the total explained variation in the $e u, Q$, and $L$ variables, respectively. So it is not true that jobs determine turnover and that any group would have equally stable 
Table 9. Sources of Racial Differences in Unemployment Flow Rates ${ }^{\mathrm{a}}$

Differentials are expressed in probabilities $\left(\times 10^{3}\right)$

Dependent variable: probability of becoming unemployed from employment ${ }^{\mathrm{b}}$

\begin{tabular}{|c|c|c|c|c|c|c|c|}
\hline & \multirow[b]{3}{*}{ Independent variable ${ }^{\mathrm{b}}$} & \multirow{2}{*}{\multicolumn{2}{|c|}{ Total, eu }} & & & & \\
\hline & & & & \multicolumn{2}{|c|}{ By quitting, $Q$} & \multicolumn{2}{|c|}{$\begin{array}{l}\text { By being } \\
\text { laid off, } L\end{array}$} \\
\hline & & $\begin{array}{l}\text { Dif- } \\
\text { fer- } \\
\text { ence }\end{array}$ & $\begin{array}{c}\text { Per- } \\
\text { cent- } \\
\text { age }\end{array}$ & $\begin{array}{l}\text { Dif- } \\
\text { fer- } \\
\text { ence }\end{array}$ & $\begin{array}{c}\text { Per- } \\
\text { cent- } \\
\text { age }\end{array}$ & $\begin{array}{l}\text { Dif- } \\
\text { fer- } \\
\text { ence }\end{array}$ & $\begin{array}{c}\text { Per- } \\
\text { cent- } \\
\text { age }\end{array}$ \\
\hline (1) & All independent variables & 4.45 & 100.0 & 1.70 & 100.0 & 6.33 & 100.0 \\
\hline (2) & Race variable only & 3.63 & 81.5 & 1.09 & 64.1 & 4.91 & 77.6 \\
\hline (3) & All personal variables & 4.60 & 103.4 & 1.46 & 85.8 & 6.10 & 96.4 \\
\hline (4) & All job variables & -0.15 & -3.4 & 0.24 & 14.2 & 0.22 & 3.6 \\
\hline
\end{tabular}

Source: Same as table 7. Figures are rounded.

a. Data for $e u$ are for 1972; for $Q$ and $L$, March 1973. Racial differential = nonwhite rate minus white rate.

b. See table 7 for descriptions or definitions of the independent and dependent variables.

experience in the same job. In fact, it is more likely that some labor-force groups will have equally stable experience in a variety of jobs, both good and bad.

\section{RACIAL TURNOVER DIFFERENTIALS}

The analysis has shown that blacks have a higher rate of transition out of employment into unemployment and that this phenomenon is the main cause of the high unemployment rates that they experience. Microanalysis can help determine the contributors to this high turnover experience. Substituting into the regression equation the independent variables averaged for whites gives the predicted turnover rate for whites. Subtracting this result from the predicted turnover rates for blacks yields the total predicted racial differential in the turnover rate. But the regression allows a decomposition of this differential, calculated by setting equal to zero the racial gaps in all except the variables under consideration.

The first row of table 9 gives the total racial differential for each of the turnover variables. The main story appears in the second row, which shows that most of the racial differential is associated with the race variable itself. About 82 percent of the difference in the $e u$ variable between blacks and whites, 64 percent of the difference in the quit rate, and 78 percent of the difference in the layoff rate is explained by the race variable. Most of the 
remaining difference reflects the other personal variables. All of the personal variables together, including race, account for 103,86 , and 96 percent, respectively, of the $e u, Q$, and $L$ variables. Only 14 percent of the racial differential in the $Q$ variable is due to the bad jobs of blacks insofar as the job characteristics are identified in these data; the corresponding figure for the $L$ variable is only 4 percent. The job variables actually tend to narrow slightly the racial differential in the $e u$ variable.

Interactive models. The weak explanatory power of job variables may be contingent upon the additive functional form chosen for the regression analysis. If an interactive specification were chosen the job variables might prove more powerful and the dual-labor-market theory might yet be vindicated.

In order to test this possibility two new models have been estimated, each allowing different coefficients on the variables for different subsamples of the population. Approximately the same equation as was used for the whole population is now fit separately to subsamples. The first disaggregation divides the labor force into young workers (under thirty) and mature workers, and the second disaggregation divides it into male and female workers. The racial differential in employment-to-unemployment turnover can again be decomposed into the part arising from personal variables and the part arising from job variables. The method is exactly the same as that used for the whole labor force.

Table 10 shows that in most cases the pure race variable, exclusive of other personal differences and job differences between blacks and whites, accounts for most of the racial difference in the turnover variables. Usually, other differentials in personal variables supply most of the remaining differential. Job differences usually account for a small part of the racial differential. There are two exceptions, both for the quit-rate variable. In the subsamples for more mature workers and for males, the race variable gives a statistically insignificant negative coefficient, rather than the positive coefficient estimated in the twelve other regressions. For these two subsamples the excess of the black quit rate over the white quit rate is very small (by comparison with the quit-rate differential in the complementary group and by comparison with the differential in layoff rates), but it is entirely accounted for by racial differences in jobs, not personal characteristics. Wherever the differentials are large they are accounted for by personal characteristics, primarily the pure race variable itself. 
Table 10. Sources of Racial Differences in Unemployment Flow Rates, by Labor Force Subgroup ${ }^{a}$

Nonwhite rate minus white rate as fraction of the employed labor force $\left(\times 10^{3}\right)$

\begin{tabular}{|c|c|c|c|c|c|c|}
\hline \multirow[b]{3}{*}{$\begin{array}{l}\text { Independent } \\
\text { variable }\end{array}$} & \multicolumn{6}{|c|}{$\begin{array}{c}\text { Dependent variable: probability of becoming unemployed } \\
\text { from employment }\end{array}$} \\
\hline & \multicolumn{2}{|c|}{ Total, eu } & \multicolumn{2}{|c|}{ By quitting, $Q$} & \multicolumn{2}{|c|}{ By being laid off, $L$} \\
\hline & Difference & $\begin{array}{l}\text { Per- } \\
\text { centage }\end{array}$ & Difference & $\begin{array}{l}\text { Per- } \\
\text { centage }\end{array}$ & Difference & $\begin{array}{l}\text { Per- } \\
\text { centage }\end{array}$ \\
\hline & \multicolumn{6}{|c|}{ Young persons (under 30) } \\
\hline All characteristics & 7.96 & 100.0 & 3.52 & 100.0 & 14.23 & 100.0 \\
\hline All personal & 7.89 & 99.0 & 3.63 & 103.0 & 13.75 & 96.6 \\
\hline Race only & 7.21 & 90.5 & 2.94 & 83.4 & 12.02 & 84.5 \\
\hline \multirow[t]{2}{*}{ All job } & 0.08 & 1.0 & -0.11 & -3.0 & 0.49 & 3.4 \\
\hline & \multicolumn{6}{|c|}{ Mature persons (30 and over) } \\
\hline All characteristics & 3.00 & 100.0 & 0.55 & 100.0 & 2.22 & 100.0 \\
\hline All personal & 2.48 & 82.4 & -0.28 & -50.7 & 2.24 & 100.9 \\
\hline Race only & 1.43 & 47.4 & $-0.24^{b}$ & -43.4 & $1.30^{\mathrm{b}}$ & 58.5 \\
\hline \multirow[t]{2}{*}{ All job } & 0.53 & 17.6 & 0.83 & 150.7 & -0.02 & -0.9 \\
\hline & \multicolumn{6}{|c|}{ Males } \\
\hline All characteristics & 6.18 & 100.0 & 0.46 & 100.0 & 5.73 & 100.0 \\
\hline All personal & 5.10 & 82.6 & -0.10 & -20.9 & 4.54 & 79.2 \\
\hline Race only & 3.92 & 63.4 & $-0.21^{b}$ & -47.0 & 3.29 & 57.4 \\
\hline \multirow[t]{2}{*}{ All job } & 1.08 & 17.4 & 0.55 & 120.9 & 1.19 & 20.8 \\
\hline & \multicolumn{6}{|c|}{ Females } \\
\hline All characteristics & 3.61 & 100.0 & 2.73 & 100.0 & 7.41 & 100.0 \\
\hline All personal & 3.73 & 103.5 & 2.84 & 104.1 & 8.21 & 110.8 \\
\hline Race only & 3.13 & 86.8 & 2.56 & 93.8 & 7.22 & 97.5 \\
\hline All job & -0.12 & -3.5 & -0.11 & -4.1 & -0.80 & -10.8 \\
\hline
\end{tabular}

Source: Same as table 7, using regressions described in the text. Figures are rounded.

a. Data for $e u$ are for 1972; for $Q$ and $L$, March 1973.

b. Race coefficient in regression insignificant at the 5 percent level.

\section{Implications of the Dominance of Personal Characteristics over Job Characteristics}

Both the analysis of variance of turnover rates and the decomposition of the racial differential in turnover rates display a major, possibly dominant, role for personal variables and diminish the importance of "bad" jobs. I can only speculate on the reason for this result. The first explanation suggested by the coefficients lies in discriminatory selection of employees for 
layoff: acting out of sheer racism, the white employer, knowing he has to discharge twenty workers, picks sixteen blacks and four whites. Alternatively, the employer may lay off blacks and young people first because they are less productive in the same job.

Youths can be expected to have shorter job tenure and therefore to be the first laid off under seniority rules, even on the same job. But why should blacks have shorter tenure than whites? Short tenure may arise from instability itself, in which case job tenure cannot of itself explain the high job turnover for blacks. The job-tenure variable would be helpful in examining these questions.

Recall that each of the dependent variables studied here measures only transitions from employment to unemployment, excluding transitions between jobs. Blacks and youths may quit and be laid off from jobs only as frequently as whites, but have higher $e u$ rates because they fail to get new jobs before separating from their old ones. In this case, as Flanagan suggests, the problem lies in finding a job rather than in keeping it. ${ }^{15}$

A final possibility is that the job variables do not measure the factors that define a high-turnover, low-attachment job. The current variables will place a worker in a particular industry and occupation, pinpoint his wages, and even indicate whether he is a fulltime or a parttime worker. Perhaps, within the same industry, occupation, wage, and workweek there are still both good and bad jobs and blacks and youths may have a disproportionate share of the bad jobs. If so, the regression would incorrectly explain it by personal rather than job variables. But the personal variables are also imprecise, which will diminish their explanatory power. Now that the standard job variables have been shown to be relatively weak in explaining job turnover, the burden of proof falls upon others to show that a new specification can reverse the conclusion. The result of this paper is corroborated by Flanagan. ${ }^{16}$

\section{Conclusion}

This paper makes an effort to sort out the causes of unemployment within the context of a dynamic labor market, examining labor flows that are

15. Robert J. Flanagan, "Discrimination Theory, Labor Turnover, and Racial Unemployment Differentials" (paper prepared under Grant 91-17-72-32 from the U.S. Manpower Administration; University of Chicago, April 1975; processed).

16. Ibid. 
overlooked in the narrow context of a two-state labor market. The further decomposition of unemployment flows in this paper allows a closer view of the behavioral relations that initiate unemployment spells and prevent reemployment. The model provides a framework in which to discuss unemployment in concrete terms such as quits, layoffs, and job accessions, terms that relate directly to the decisions of firms and workers. The excess of unemployment reported for nonwhites, women, and teenagers is found to result mostly from excessive job losses and quits, rather than from any special difficulty in finding jobs. Employed women are found to have a high propensity to leave the labor force, apparently for noneconomic reasons. Blacks become unemployed through job separation in much greater proportion than whites. A great many teenagers separate from their jobs, some leaving the labor force and others becoming unemployed.

In contrast to the unemployment of special population groups, cyclical unemployment occurs because firms close the hiring window. With the onset of recession, unemployment spells lengthen dramatically and new entrants to the labor force find it difficult to get jobs. None of these are startling conclusions, but they have never before been derived from a complete model with flows among all three possible states of the labor market.

Cyclical changes in unemployment aside, the analysis reveals a striking dominance of personal characteristics in explaining high job turnover. Some population groups, notably blacks, teenagers, and uneducated people, are found to suffer frequent layoffs irrespective of their jobs. In particular, the high turnover rates experienced by black workers are found to have little connection with the jobs they are in. A black working in the same job as a white will be somewhat more likely to quit and much more likely to be laid off. This type of result dominates any direct evidence that would favor the dual-labor-market theory that high job turnover is primarily the result of bad jobs.

The results of this paper are useful in analyzing manpower policies. For example, the provision of public jobs in nonrecessionary times cannot be expected drastically to reduce the unemployment rates of blacks, women, and teenagers, because the excess unemployment rates suffered by these groups are not caused primarily by their inability to find jobs. The impact would be particularly small if the programs were closed to new labor-force entrants, one of the features of the usual proposals.

Aggressive stabilization policies must play a big role in reducing the duration of unemployment. But even in an economy in which monetary and 
fiscal policies have established aggregate demand at a high level, unemployment among blacks, women, and teenagers will still be relatively high because of excessive job outflows. Apparently, even providing more good jobs for these groups will not eliminate their turnover problems. The labor-force exits of women and teenagers will be difficult to reduce because they are mostly noneconomic and are dictated by societal norms about the roles of women and youths. However, the involuntary job losses of blacks suggest a possible discriminatory discharge policy. Further research may point to policies to reduce such actions.

\section{APPENDIX}

\section{Estimation of Partial Differences in Unemployment Rates}

Equation 11 is exactly true for only infinitesimal variations in the flow rates. ${ }^{17}$ Between any two groups-say, teenage and mature workers-there is a discrete jump, $\Delta p_{i}$, in each flow rate. This jump can be thought of as the integral of infinitesimal changes, $d x$, over each of which the partial derivative of the unemployment rate with respect to the flow rate is fixed. The $i$ th partial difference is then

$$
\Delta u_{i}=\int_{p_{1 i}}^{p_{2 i}}\left(\frac{\partial u}{\partial p_{i}}\right)_{x} d x
$$

The problem is evaluating $\left(\partial u / \partial p_{i}\right)_{x}$, the value of the derivative at a point $x$ intermediate between the first group's flow rates, $p_{1}$, and the second group's flow rates, $p_{2}$. For this purpose it is assumed that

$$
\begin{gathered}
\left(\frac{\partial u}{\partial p}\right)_{x}=\left(\frac{x-p_{1}}{p_{2}-p_{1}}\right)^{a}\left(\frac{\partial u}{\partial p_{2}}-\frac{\partial u}{\partial p_{1}}\right)+\left(\frac{\partial u}{\partial p_{1}}\right) \\
p_{1} \leq x \leq p_{2} \\
a \geq 0,
\end{gathered}
$$

17. The analysis in this appendix was suggested to me by Leonard Herk. 
where the subscript $i$ has been dropped and $\partial u / \partial p_{1}$ is the derivative of the unemployment rate evaluated at $p_{1}$. Notice that this derivative is $\partial u / \partial p_{1}$ if $x$ is $p_{1}$, and $\partial u / \partial p_{2}$ if $x$ is $p_{2}$. The path of the derivative between $p_{1}$ and $p_{2}$ is a straight line if $a=1$, and a curved, continuous line otherwise. Evaluating the above integral, the $i$ th partial difference becomes

$$
\Delta u_{i}=\left[\left(\frac{a}{a+1}\right) \frac{\partial u}{\partial p_{1 i}}+\left(\frac{1}{a+1}\right) \frac{\partial u}{\partial p_{2 i}}\right] \Delta p_{i},
$$

so each of the partial differences of unemployment rates is found by multiplying the difference in flow rates by a weighted average of unemployment derivatives. The $a$ is estimated by requiring that the partial differences add up to the total difference in unemployment rates, giving

$$
\hat{a}=\frac{\sum_{i}\left(\frac{\partial u}{\partial p_{2 i}}-\frac{\partial u}{\partial p_{1 i}}\right) \Delta p_{i}}{\Delta u-\sum_{i} \frac{\partial u}{\partial p_{1 i}}}-1 .
$$

In all cases $\hat{a}$ is in the neighborhood of one. Therefore, the derivative in equation A-3 is near the simple average of the derivatives evaluated at the flow rates of the first group and of the second group. 


\section{Comments and Discussion}

Martin Feldstein: Stephen Marston has given a very useful paper, or, more accurately, two very useful papers. He has analyzed the data on gross flows to estimate the importance of the different flows as sources of unemployment; and he has examined the factors associated with quits and layoffs. I found the estimated transition rates and the decomposition of unemployment differences particularly interesting.

I want to comment on three issues of interpreting the data that Marston has produced. First, how should the substantial rates of flow out of the labor force (un and en) be interpreted? When an unemployed person is reclassified as out of the labor force $(U N)$, is this an indication that he is a "discouraged worker"? This transition is most common among young people, but in this group the movement from employment to "out of the labor force" without any job search is also very common (en varies from 0.12 among white males aged 16 to 19 to 0.20 among nonwhite females in that age group). Moreover, when the Current Population Survey asks why males are not in the labor force, less than 2 percent say that it is because they think they cannot get a job. I think it is therefore difficult to say that durations of unemployment are as short as they are because workers become discouraged and stop looking.

As I understand the data of table 1, the most striking difference between men and women is in the probability of leaving the labor force from employment (a factor of 13 for mature whites) rather than from unemployment (a factor of less than 3). Women withdraw from the labor force voluntarily much more readily than men do. It would be interesting to carry Marston's analysis further by separating quits and layoffs and by distinguishing the temporarily laid off (who are counted as unemployed even if they do not search) from other unemployed (who must search to be 
counted). It would also be useful to separate reentrants; some 40 percent of unemployed women are reentrants who may search temporarily and then, finding no jobs that they like, stop searching and are then counted as not in the labor force. This is likely to be a particular problem since the CPS may itself induce temporary job search (including talking to friends, looking at newspaper ads, and the like) that otherwise would not have occurred.

To analyze the factors influencing quits, Marston used the March 1973 Current Population Survey and defined a binary variable to be equal to 1 if the individual was unemployed for three weeks or less and became unemployed by quitting. A similar variable was defined for job losers. These variables were then regressed on a large number of personal and job characteristics. Marston discusses the effect of particular factors on the probability of quitting or being laid off. He also concludes more generally that the probability of a quit or a layoff depends more on the characteristics of the individual than on the characteristics of the job. I have several problems with this analysis. First, I do not believe that Marston has adequately measured the spells of unemployment that result from quitting or being laid off. There are two aspects of this problem. Many of those who become unemployed do not remain unemployed for as long as three weeks. In March 1973, 41 percent of those found by the survey to be unemployed had been unemployed for four weeks or less. Since this is unemployment to the date of the survey, an even higher fraction of those who become unemployed do not remain so for that period. Anyone who stops being unemployed within the three weeks ( $U E$ or $U N$ ) will not be included in Marston's count. Since durations differ significantly among demographic groups, the estimated coefficients will be biased. The second aspect is that many who quit or are laid off do not directly become unemployed but pass through a period of being out of the labor force $(E N)$ before seeking work $(N U)$. Table 1 shows that both of these flows are substantial. Marston's method ignores both the $E N$ and $N U$ sources of unemployment caused by quits and layoffs. The "wrong" effect of age is probably due to this.

Even if the dependent variables were correctly measured, I would doubt Marston's conclusion that the characteristics of the job have so little importance in determining unemployment. I have argued at length elsewhere that the instability of employment of disadvantaged young people is due in large part to the kinds of dead-end jobs in which they find themselves 
and have suggested a policy of government training grants to help these young people. ${ }^{1}$ Does Marston's evidence really show that it is not the jobs that are responsible for this instability but some inherent fault of the young people? One difficulty with his analysis is that it combines people of all ages. I believe that job quality is much more important for young people than for mature workers who may have no hope of a better job and who have much greater financial responsibilities. The same is true for those on the border between work and welfare. Moreover, Marston's measures of job characteristics are limited to twelve occupations, fourteen industries, and the wage rate. It is not surprising that none of these variables is statistically significant. There is no indication of the characteristics that should matter most in a young person's decision to quit a job or his employer's decision to lay him off permanently: on-the-job training, the internal job ladder, seniority rules, and the like.

Saul H. Hymans: Steve Marston has written two papers, one on the $3 \times 3$ table of flows, and the other an attempt to follow up the leads suggested by the flow data.

I loved the first paper. It's a fascinating and significant addition to the literature on labor-market flows, and it brings to light much that we-or at least I-didn't know before. It raises a host of important questions that beg to be answered. The second paper is somewhat less successfulmostly, but not entirely, because of data limitations.

One of the principal findings of the first paper is that, compared to men, women leave employment with greater frequency-enough to account for a differential in unemployment rate of 4 percentage points. But the female job exiters also leave the labor force with greater frequency than men, so proportionately, many fewer wind up on the unemployment rolls and the net differential is about $1 \frac{1 / 2}{2}$ percentage points.

There are important variations around this average pattern. For example, black teenage females suffer much higher unemployment than black teenage males ( 7 percentage points) not only because they exit from employment more frequently, but-even more important-because they are grossly unsuccessful at finding jobs when they enter the labor force. Indeed, comparing men and women, job prospects upon entering the labor force

1. Martin S. Feldstein, Lowering the Permanent Rate of Unemployment, A Study Prepared for the Use of the Joint Economic Committee, 93:1 (GPO, 1973). 
look bad for all women other than white women over 25 , and such women are numerous enough to tip the overall average to a meaningless zero. In fact, no women of any demographic group "look just like men" upon entering the labor force: mature white women are somewhat more easily employed, all the other women are far less quickly employed.

A second variation in the average pattern of men exiters compared with women exiters is that black women in their early twenties leave unemployed status with far greater frequency than do black men in that age group, but do so by dropping out of the labor force.

In a second part of Marston's analysis, racial comparisons also reveal a distinct average pattern with substantial demographic variation around the average. On the average, blacks leave employment more frequently, leave unemployment less frequently (higher duration of unemployment), and have a tougher time finding jobs when they enter the labor force. But for one thing, mature black males exit from unemployment with about the same frequency as mature white males; there is no appreciable difference in duration of unemployment; and mature black men have no greater difficulty than whites in finding jobs either when they are unemployed or when they enter the labor force. For another, mature black women suffer in comparison with mature white women only upon entering the labor force. They don't leave jobs any more frequently, and they don't stay unemployed any longer; nor do they leave the labor force quite as quickly upon exiting from employment.

How should one proceed from this point? Marston observes that job exits are of much greater importance as a determinant of differences in unemployment rate than any other single characteristic; and he sets out to analyze the flow out of employment. Consider the $e u$ regression in table 7.

The sex variable tells us that women have a significantly lower probability of moving from employment to unemployment. But the information in table 4 tells us that that behavior is important for young females-all teenagers and whites in their early twenties.

The race variable indicates that blacks have a significantly higher probability of going from the employed to the unemployed status. But the data in table 4 tell us that this is relatively unimportant for black males in their early twenties and for mature black females-that it is primarily a problem for black teenagers and, in comparison with other flows, that it is critical for mature black men. 
I seem to learn very little from the regressions in table 7 . While the regressions add dimensions, such as industry and family status, that are not present in the original flow data, they assume an additivity of demographic characteristics that the flow data cry out to reject. The flow data suggest that being young always hurts, but that being black hurts primarily if you are black and young: that's interaction of race and age, not additivity of race and age.

Marston does present interactive models and summarizes the results in table 10. Those results clearly support the finding that race matters in the transition from employed to unemployed status, as Marston first found in connection with the additive model in table 7 . But the quantitative signicance of the race variable is evidently very different for workers who are young, female, or both than it is for workers who are older, male, or both. The results in table 10 thus support both Marston's qualitative conclusions and my suspicion that quantitative effects are better measured in an interactive model.

\section{General Discussion}

Robert Hall viewed the paper as extending and supporting earlier analyses of turnover as the critical determinant of unemployment rates. But he deemed it impossible to allocate explanatory contributions among variables in regressions, as Marston tries to do with job and personal variables in explaining turnover. So much of the explanation is shared by the two sets of variables that little can be proved by the regressions in the paper. Hall pointed out the parallel with the Coleman report, which arbitrarily attributed educational achievement to homes rather than schools by a similar method. Robert Solow insisted on the need to look at the variation of job and personal independent variables as well as at the impact of a given change in these variables upon turnover. Martin Feldstein added that the job and occupational categories were probably too broad to address the question of the importance of job characteristics to employment experience. Despite these problems, Arthur Okun thought the results surprising and interesting, even if inconclusive. He would have thought that the job categories would have more explanatory power in the regressions if they were in fact important. 
Feldstein stressed the ambiguity in categorizing the unemployed according to whether they had just left employment or had just entered the labor force. A person who fails to search for a new job immediately after losing his previous job may be omitted from the quit or layoff category because he is counted as out of the labor force. This may especially distort comparisons between older workers and young ones since the latter are more likely to leave the labor force temporarily. But R. J. Gordon noted that counting brief spells out of the labor force as unemployment would be misleading too, because a teenager with a brief nonparticipation stage between two unemployment periods would appear to have a very long duration of unemployment. As a result, the casual nature of teenagers' attachment to the labor force would be concealed.

Marston reminded the panelists that a bias in the quit and layoff variables, which misclassify a few unemployed as out of the labor force, is balanced by the opposite bias in his $e u$ variable, which is calculated from retrospective data. For these data, respondents are asked how many spells of unemployment they had in the previous year, and they are very unlikely to count a long spell as two spells of unemployment just because they did not search during a week in the middle. This $e u$ variable agrees very closely with the sum of the quit and layoff variables, indicating that the omissions in each are not serious.

June O'Neill thought the analysis was severely weakened by the absence of a variable measuring job tenure. She noted that tenure was probably the single most important factor determining who gets laid off in any occupation, and therefore it should be explicitly allowed for in analyzing the importance of other job or personal characteristics.

R. A. Gordon cautioned against drawing conclusions from the 1967-73 period used in the analysis. The secular declines in nonwhite male participation rates and the increase in female participation rates over this period may cloud the results. Michael Wachter found that the period used limited the analysis because it included only a relatively mild recession without massive layoffs. He therefore thought its results characterized the operation of a high-employment economy rather than the unemployment experienced during cyclical periods.

R. J. Gordon concluded from the results on sex differences that women have two basic problems in the labor market, both of them "noneconomic." The first is a "husband problem," causing them to drop out of the labor 
force frequently and then run a high risk of unemployment when they subsequently reenter. The second is the occupational-crowding problem, which gives them low wage rates in their traditional occupations. He also attributed teenage turnover not to a fundamental problem of job availability, but to a rational unwillingness of teenagers to be tied down to a blue-collar job so early in their lives. 